\title{
AMERYKA W POEZJI ANNY FRAJLICH
}

\author{
Agnieszka ŻMUDA (Katolicki Uniwersytet Lubelski Jana Pawła II)
}

Ameryka była dla Anny Frajlich miejscem wygnania z Polski, bowiem poetka znalazła się tam na skutek wydarzeń marcowych 1968 r. Tak też opisywała ją w swojej początkowej poezji emigracyjnej (mowa tu szczególnie o tomikach: Aby wiatr namalować i Tylko ziemia ${ }^{1}$ ). W wierszach późniejszych, a szczególnie tych ostatnich (wydanych w latach 2000-2013), Ameryka staje się powoli miejscem zadomowienia. Czy jednak kontynent ten wyznacza kres poetyckiej wędrówki Anny Frajlich, odbywanej od prawie pięćdziesięciu lat? Wygnana ciągle metaforycznie wędruje, szuka swojego domu, miejsca, które będzie jej na zawsze. Poezja ta stanowi przykład świadectwa, które ujmuje doświadczenia wielu lat w metaforycznym skrócie, broni „zawsze jedności i wyjątkowości ludzkiego życia"2.

\section{Ameryka - miejsce wygnania}

Emigrantka przeżywała doświadczenie wygnania bardzo emocjonalnie, co jasno widać w zapisach poetyckich z tego okresu. Tracąc swoją ojczyznę, straciła wszystko, co w niej posiadała: dom rodzinny (jako miejsce zamieszkania, z którym się mocno utożsamiała), rodzinę, przyjaciół, zgromadzony dobytek, łączność z kulturą polską, językiem. Na nowym kontynencie została skazana na samotność i anonimowość, musiała na nowo zbudować swój wizerunek, nawiązać kontakty towarzyskie, zweryfikować tożsamość, która poprzez wypędzenie została naruszona ${ }^{3}$. Wszystko to spowodo-

${ }^{1}$ A. Frajlich, Aby wiatr namalować, Londyn 1976; taż, Tylko ziemia, Oficyna Poetów i Malarzy, Londyn 1979. s. 372 .

2 J. Żmidziński, Drzewo i dom. O wierszach Anny Frajlich-Zając, Polonistyka 1998 nr 6,

${ }^{3}$ Czynnikami, które budują tożsamość człowieka są m.in. identyfikacja narodowa i religijna. W obliczu radykalnych zmian zachodzi potrzeba zachowania wierności sobie i poczucia podmiotowej ciągłości. Tożsamość, aby się odbudować, potrzebuje wzmacniania i powtarzania; por:: E. Micha, Etyczny wymiar tożsamości etnicznej w sytuacji zmiany identyfikacji narodowej, [w:] Etyczny wymiar tożsamości kulturowej. Studia z antropologii społecznej, red. M. Flis, Kraków 2004; C. Taylor, Etyka autentyczności, tłum. A. Pawelec, Kraków-Warszawa 1996; C. Taylor, 
wało, że tuż po przyjeździe Ameryka była widziana przez nią jako Babilonia — kraina, gdzie możliwy jest tylko płacz i lament za utraconą Ziemią Obiecaną ${ }^{4}$. Jej los wpisuje się w historyczne doświadczenie Żydów, jakim jest wygnanie ${ }^{5}$. Babilonia to miejsce zesłania, kary za niewierność i służenie obcym bogom. $Z$ tego powodu staje się ona w kulturze żydowskiej symbolem zła, zepsucia, grzechu, lecz także cierpienia i oczyszczenia - powrócą z niej tylko wybrani, Reszta Jakuba ${ }^{6}$. Zarazem jednak, z historycznego punktu widzenia, dochodzi tam do ważnych wydarzeń ${ }^{7}$. Dla niektórych Żydów staje się ona paradoksalnie nowym Kanaan, tak że nie powracają już nigdy z wygnania. Bohaterka Frajlich, podobnie jak oni, przechodzi w swojej świadomości różne etapy oswajania swojej Babilonii - Ameryki ${ }^{8}$.

Osoba mówiąca w wierszach, żydowska emigrantka z Polski, nie czuje się na kontynencie amerykańskim bezpiecznie. Jest zagubiona w nowej rzeczywistości, obca, postrzega siebie jako inną. Najpełniej ten stan obrazuje umieszczony na początku pierwszego tomiku poetyckiego wiersz ***Jestem oddzielna (ABW, s. 10)

Źródta podmiotowości: narodziny tożsamości nowoczesnej, tłum. M. Gruszczyński, Warszawa 2001. Badania psychologiczne potwierdzają, że każda migracja, a w tym szczególnie przymusowa, pozostawia ślad w psychice i obejmuje całą osobowość. Dochodzi do zakwestionowania tożsamości, a w rezultacie do ponownego samookreślenia i redefinicji; zob.: J. Kubitsky, Psychologia migracji, Warszawa 2012.

${ }^{4}$ Babilonia to kraina wygnania Żydów po zburzeniu Jerozolimy przez babilońskiego króla Nabuchodonozora w 597 r. p.n.e.; zob.: Jr 39,2; 52,7.12; 2 Krl 24, 19; 25, 1-4. W Biblii wygnanie to (księga Lamentacji Jeremiasza oraz Psalm 137) jest opisywane jako szczególnie dotkliwe. Wszystkie cytaty z Pisma Świętego pochodzą z wydania: Biblia Jerozolimska, tłum. zespół biblistów, wstępy, przypisy, komentarze i marginalia tłum. zespół pod kier. ks. A. Cholewińskiego i bp. Z. Kiernikowskiego, Poznań 2006.

${ }^{5}$ Warto w tym miejscu wymienić niektóre z wypędzeń, które stały się udziałem Żydów: począwszy od czasów starożytnych — pierwsze (ok. $722 / 720$ r. p.n.e.) i drugie wygnanie babilońskie (597-537 p.n.e.), wygnanie po zburzeniu Drugiej Świątyni (70 r. n.e.), poprzez nowożytne — wygnanie Żydów z Hiszpanii w 1492 r., wszystkie, które towarzyszyły Zagładzie, aż po wygnanie z Polski w marcu $1968 \mathrm{r}$.

${ }^{6}$ Zob.: Syr 48, 15-16; Iz 10, 20-22.

${ }^{7}$ Właściwa historia judaizmu jako nowoczesnego systemu religijnego rozpoczyna się właśnie w Babilonii. Tam rodzą się fundamenty tradycji żydowskiej, które są obecne w niej do dziś — redakcja ostatecznej formy Pięcioksięgu oraz powstanie instytucji synagogi; zob.: Z. Borzymińska, Niewola babilońska [w:] Polski stownik judaistyczny. Dzieje - kultura - religia ludzie, oprac. Z. Borzymińska, R. Żebrowski, Warszawa 2003, t. 2, s. 229-230.

${ }^{8}$ Psychologia wyróżnia fazy, które przechodzi emigrant, są to kolejno: faza szoku (stan bezradności, lęku i niepewności, kryzys tożsamości), reakcji (powolne zrozumienie swojej sytuacji, powracanie we wspomnieniach do kraju ojczystego i ocena strat), naprawy/przepracowania (zachowania adaptacyjne), reorientacji (początek nowej egzystencji); zob.: J. Kubitsky, Psychologia migracji.

${ }^{9}$ Dla oznaczenia źródła danego wiersza używam skrótów, cyfrą arabską wskazując numer strony. ABW - Aby wiatr namalować, Londyn: Oficyna Stanisława Gliwy, 1976; BDATW Between Dawn and the Wind, wyd. 2, Austin: Host Publications, 2006; DZO - Drzewo za oknem (arkusz poetycki z grafikami Bartka Małysy), Nowy Jork 1991; IS — Indian Summer, Albany: Sigma Press, 1982; JWD - Jeszcze w drodze. Wybór wierszy, Warszawa: Niezależna Oficyna Wydawnicza „Nowa”, 1994; KL — Który las, Londyn: Oficyna Poetów i Malarzy, 1986; OIO - Ogrodem i ogrodzeniem, Warszawa: Czytelnik, 1993; TZ - Tylko ziemia, Londyn: Oficyna Poetów i Malarzy, 1979; WSL - W stońcu listopada, Kraków: Wydawnictwo Literackie, 2000; ZSMW — Znów szuka mnie wiatr, Warszawa: Czytelnik, 2001; ŁJIJP — Łodzia jest i jest przystania, Szczecin: Wydawnictwo FORMA, 2013. 


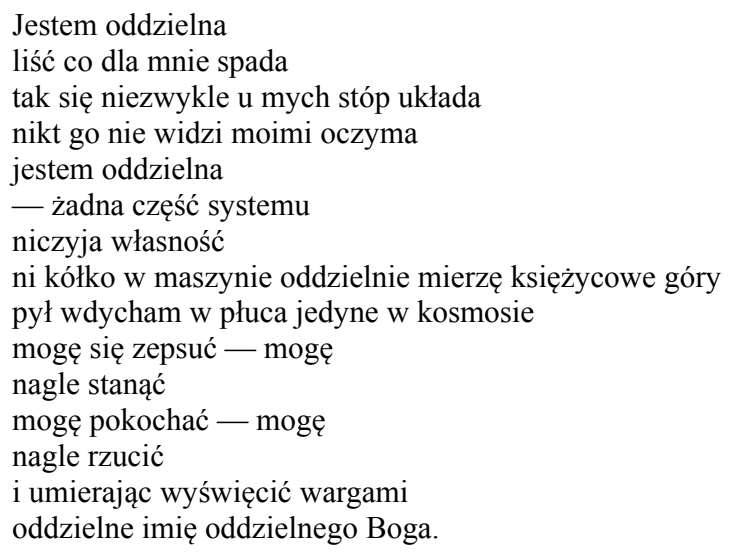

[grudzień 1973]

Utwór ten jest wyznaniem, punktem wyjściowym dla prezentacji siebie w kolejnych lirykach. Wygnana konsekwentnie, krok po kroku, przedstawia swój ambiwalentny stosunek do Ameryki. Czyni to w sposób bardzo subtelny. Jest bowiem osobą, która postrzega świat z niezwykłą wrażliwością. Nawet opadający liść układa się przed jej oczami w wyjątkowy sposób, ma swoje znaczenie. Tak widzieć może tylko artysta poeta $^{10}$. Jednak to nie jest główna cecha, stanowiąca o jej oddzielności. Czuje się inna, gdyż nie przynależy do żadnego systemu geopolitycznego. Nie jest już obywatelką Polski, a nie czuje się jeszcze Amerykanką - w ręku ma kartę wyjazdu z PRL, w świetle tego dokumentu jest bezpaństwowcem. Jest osobą wolną — nie musi bać się systemu totalitarnego, od którego uciekła, nie podlega jego prawom - lecz zarazem jest wygnana.

Florian Śmieja charakteryzuje ową cechę jako „nieprzydatność do thumu, do banalnej jednomyślności”" . Jest „oddzielna” także, a może przede wszystkim dlatego, że „oddzielnie mierzy księżycowe góry” i, umierając, może „wyświęcić wargami / oddzielne imię oddzielnego Boga". Fragmenty te wskazują na żydowskie pochodzenie bohaterki. Księżyc w kulturze wielokrotnie utożsamiany był z narodem żydowskim, który posługiwał się przy odmierzaniu czasu kalendarzem księżycowym, a nie słonecznym. Ów znak astralny przewija się przez całą twórczość Frajlich jako symbol przynależności do narodu wybranego. W wierszu, tak jak w tradycji judaistycznej, nie zostaje wprost przytoczone imię Boga ${ }^{12}$. Jest On nazwany „Bogiem oddzielnym”. Przymiotnik „oddzielny” łączy Boga i kobietę, mówiącą w wierszu, odsyłając jednocześnie do pierwszego wersu utworu, który głosi: ,jestem oddzielna”. Sam zaś czasownik ,jestem" stanowi przecież część imienia Boga Eheje-Aszer-Eheje (hebr. 'Jestem-Który-Jestem'). Zastosowana tu subtelna gra słowna potwierdza, poprzez wierność tradycji, pochodzenie żydowskie, które jest głęboko związane z doświadczeniem wygnania. Mówiąca w wierszu ze względu na swoje pochodzenie, doświadczenia, które ją

\footnotetext{
${ }^{10}$ Według Stanisława Wygodzkiego „Ta oddzielność to najprawdziwsza substancja poezji lirycznej: oddzielność widzenia, oddzielność odczuwania, oddzielność pamiętania, oddzielność interpretacji”; tenże, Zwierzenia spisane wierszem, Nowiny Kurier 21.10.1977, s. 8.

${ }^{11}$ F. Śmieja, Malarka wiatru, Związkowiec $1977 \mathrm{nr} 8$.

${ }^{12}$ Imię Boga w tradycji judaistycznej może być przywoływane tylko raz w roku i może dokonać tego tylko kapłan; zob.: G. Scholem, O głównych pojęciach judaizmu, tłum. J. Zychowicz, Warszawa 1989, s. 6-7.
} 
w życiu spotkały, została boleśnie „oddzielona” od ludzi. Chociaż jest wyjątkowa, ma szczególną wrażliwość, wdycha pył „w płuca jedyne w kosmosie”, nadal pozostaje zwykłym człowiekiem. Pragnie miłości, akceptacji, sama też może pokochać. Zdaje sobie sprawę ze swojej ułomności, ale także i siły, która wynika z możliwości wyboru. Bycie obcą w nowym środowisku bywa także naznaczające, zaczyna doskwierać i determinuje jej postępowanie:

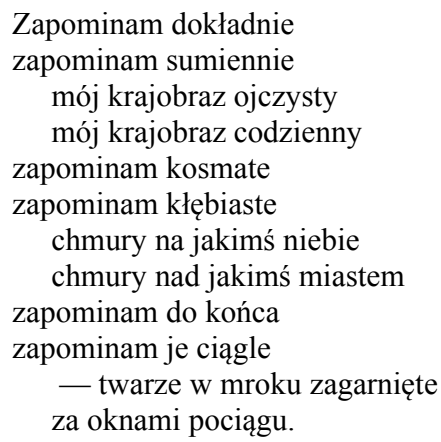

[1973]

Aklimatyzacja (ABW, s. 28)

Wygnana chce zaaklimatyzować się w nowym środowisku, na co wskazuje tytuł, ale aby tego dokonać, powinna wyzbyć się wszystkiego, co stanowi o jej inności. Wydaje się jednak, że nie jest to przymus zewnętrzny, narzucany przez środowisko amerykańskie, tylko jej wewnętrzny nakaz. Zapominanie staje się więc środkiem, który ma służyć integracji. Poetka bardzo chce zapomnieć swoją ojczyznę oraz twarze żegnających ją na Dworcu Gdańskim w Warszawie. Kosmate i kłębiaste chmury nie tylko przedstawiają fragment świata polskiej natury, symbolizują także trudne, burzliwe, bolesne wydarzenia, które rozegrały się „na jakimś niebie”, w jakimś mieście. Dlatego tak mocno stara się o wymazanie ich z pamięci. Chce się wyzbyć wszystkich wspomnień, które przypominają jej wygnanie, przyczynę pobytu w Ameryce. Reminiscencje przeszłości potęgują poczucie obcości, a mimo to okazują się bardzo trudne, a nawet niemożliwe do wyrzucenia z pamięci ${ }^{13}$, gdyż trzeba je „ciągle” i „do końca” zapominać.

Powtarzanie słowa „zapominam” ma charakter anaforyczny i pełni funkcję niemalże magiczną ${ }^{14}$. Proces zapominania przez ciągłe powielanie, dokładność i sumienność przypomina naukę i zdaje się pełnić rolę zgoła odmienną niż ta sugerowana w utworze: zamiast wymazywać z pamięci konkretne wspomnienia, na nowo je przywołuje i dzięki temu utrwala. Tekst ten jest więc paradoksalnie paralelny z wierszem Niezapominajki (saga) (IS, s. 8), który ma za zadanie zachować miejsce wygnania rodziców poetki Lwów - w pamięci, co szczególnie podkreślają poniższe wersy:

$$
\begin{aligned}
& {[\ldots]} \\
& \text { fotografia w ramce na ścianie } \\
& \text { na tej ramce niezapominajki }
\end{aligned}
$$

${ }^{13}$ Zob.: A. Frajlich, N. Gross, Anna Frajlich: o sobie i o swoich wierszach, Nowiny Kurier 17.08.2001, s. 17. W tym artykule poetka podkreśla, że niemożliwość zapomnienia jest spowodowana „bólem, poczuciem ważności i niepowtarzalności przeżyć dzieciństwa i młodości”.

${ }^{14}$ A. Węgrzyniakowa, Życie w podróży. O liryce Anny Frajlich, [w:] „Ktokolwiek jesteś bez ojczyzny...”, red. W. Ligęza, W. Wyskiel, Łódź 1995, s. 302. 


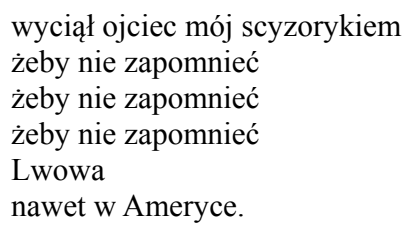

Fraza „nie zapomnieć” została użyta trzykrotnie, „zapominam” w Aklimatyzacji, natomiast zostało powtórzone sześciokrotnie, czyli jeszcze bardziej wzmocnione. $\mathrm{W}$ obu utworach zastosowany jest ten sam czasownik, chociaż użyty w innym znaczeniu, formie $i$ aspekcie. Mimo że sens słów „zapominam” " i ,nie zapomnieć” jest przeciwny, to wydaje się, że ich wymowa jest tożsama. Proces nieskutecznego zapominania (czas teraźniejszy, aspekt niedokonany — wskazuje na ciągłość zjawiska, jego aktualność) okazuje się bowiem owym nie-zapominaniem.

Poczucie wyobcowania powoduje niemożliwość zadomowienia się w Ameryce. Podmiot mówiący dostrzega, że jest to miejsce, które może stać się nowym domem. Jednak na tym etapie emigracji w postrzeganiu dominują przede wszystkim różnice pomiędzy ojczystą przestrzenią polską a amerykańską. Najcelniej obrazuje to opozycja polskie - amerykańskie, wpisana w wiersz Spacer po Nowym Jorku (ABW, s. 32), szczególnie obecna w podkreślonych wersach ${ }^{15}$ :

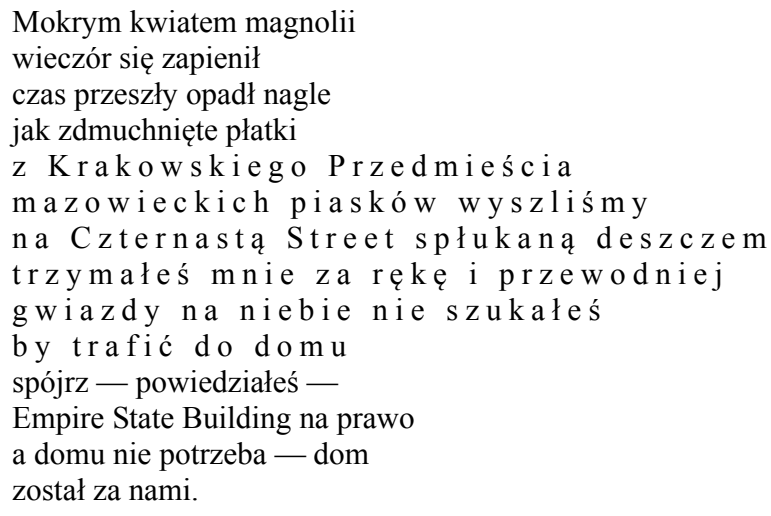

[Nowy Jork 1973]

Polska uobecniana jest w wierszu poprzez „mazowieckie piaski” oraz „Krakowskie Przedmieście”. Pierwszy epitet odsyła do obrazu konotującego przyjemne chwile, do wakacyjnego odpoczynku na plaży, wygrzewaniu się w słońcu, to z pewnością miłe wspomnienia. Drugi zaś to reprezentacyjna ulica stolicy, charakterystyczna, tradycyjnie utożsamiana z Warszawą - stanowiąca symbol tego miasta, miejsca, skąd bohaterka musiała wyjechać. Dla kobiety jest znakiem czasu przeszłego - naznaczonego zarówno cierpieniem, jak i radością, który „opadł nagle”, zniknął. Przeciwieństwem Polski jest Ameryka, reprezentowana przez Nowy Jork. Przywoływane elementy miejskiego pejzażu symbolizują nowoczesne centrum, postęp. Sam zaś deszcz to oczyszczenie, obmycie, które może być wyrazem nowego początku, cechującego się uwolnieniem od przeszłości, traumatycznych warszawskich wspomnień. Wygnańcy nagle, tak jakby przenieśli się w przestrzeni, spacerując po Warszawie, wchodzą na amerykańską ulicę. Ta zmiana, która nastała nieoczekiwanie, jest jak drastyczne, przedwczesne przekwit-

\footnotetext{
${ }^{15}$ Wszystkie podkreślenia wersów w utworach pochodzą od autorki artykułu.
} 
nięcie magnolii. Co ciekawe, chociaż Ameryka jest symbolem teraźniejszości, dla nich nie jest domem: „, domu nie potrzeba - dom / został za nami”. Pragną tego domu, jednak zdają sobie sprawę, że powrót do niego jest niemożliwy. Wiedzą, że nie należy szukać ,przewodniej gwiazdy”, która do niego prowadzi.

Pragnienie domu, własnego miejsca w topografii miasta, jest u mówiącej bardzo silne, czego wyrazem jest wiersz Bez adresu (OIO, s. 64). Ów tytułowy adres stanowi nie tylko konkretne odesłanie do miejsca zamieszkania, cyfry w bramach, jest to część tożsamości, która pozwala na przynależność ${ }^{16}$. Poetka chce posiadać właściwy adres, z którym będzie mogła się identyfikować, nazwać go swoim na zawsze, tak jak, mimo różnych kolei losu, uczynił Isaac Bashevis Singer. Jego warszawski adres był z nim utożsamiany przez całe życie, wedle zasady wypowiedzianej przez niego w pierwszej strofie wiersza: „- Pisarz powinien mieć adres —.". Owa identyfikacja nie jest prosta, gdyż jej życie naznaczone jest wygnaniami, a co za tym idzie zmianami adresów, różnymi ulicami, które ciągle powracają na jawie i we śnie, i nie dają się zapomnieć. Istnieją one jednak już tylko w jej pamięci, nie należą do rzeczywistości, w której aktualnie się znajduje, dlatego nie wie już, „co jest moje co obce”. Wiersz jest przesiąknięty tęsknotą za własnym miejscem, żalem za tym straconym domem. Frajlich pokazuje w ten sposób doświadczenie wygnania jako formę bezdomności, opisuje trudności $\mathrm{z}$ akceptacją swojej historii, akcentuje poczucie inności — każdy ma adres, bez niego żyją tylko wygnańcy.

Emigrantka doświadcza różnych negatywnych odczuć, związanych z nowym położeniem. W Ameryce zmaga się z wieloma trudnościami, które powodują niechęć do tego kraju. Zarazem Polska jako miejsce, gdzie doświadczyła prześladowania i upokorzenia, też kojarzy się jej negatywnie. Nadal czuje się pokrzywdzona i bezradna. Strata domu, bezpieczeństwa, ciągła niepewność powodują u niej kryzys tożsamości. Nie wie także, czy dokonała prawidłowego wyboru, bo życie w Ameryce naznaczone jest zbyt wieloma przeciwnościami. Czuje rozdarcie pomiędzy „wolnością”, którą otrzymała na obczyźnie, a krajem lat dziecinnych. Jej kondycję doskonale pokazuje wiersz Rozmyślania wyzwoleńca (KL, s. 20), oddający pogląd samej wygnanej i tragiczność jej sytuacji:

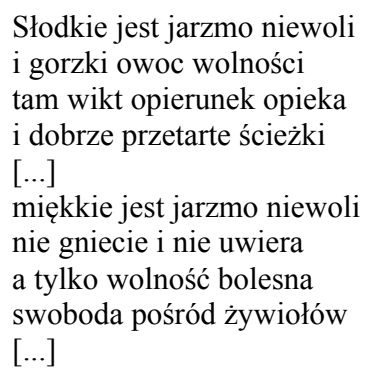

Utwór przypomina opisane w Biblii szemranie narodu wybranego na pustyni, skierowane przeciwko Bogu ${ }^{17}$. „Niewola” charakteryzowana jest pozytywnie. Tak z perspektywy czasu i trudności, z którymi musi się teraz zmierzyć, widzi ją wygnaniec. Jednak niewola to, jak sama nazwa wskazuje, brak wolności, swobody, to życie pod kontrolą, w jarzmie. Wolność, „swoboda pośród żywiołów” jest cięższa, bardziej

${ }^{16}$ Dom wydaje się szczególnie ważny dla poety, który jest utożsamiany z konkretnym miastem, krajem. „Wygnanie pozbawia poetę wyróżniającej sygnatury”; W. Ligęza, Poeta emigracyjny. Role i wyobrażenia, [w:] Literatura a wyobcowanie, red. J. Święch, Lublin 1990, s. 89.

${ }^{17}$ Zob.: Wj 16, 3; Lb 11, 1-15. 
wymagająca, gdyż samemu należy zajmować się swoim życiem, ponosić konsekwencje swoich decyzji. Jednak to właśnie dzięki wolności można „skrzydła rozwijać i zwijać”, wykorzystywać talenty, rozwijać się. Najważniejszą cechą, która decyduje o zwycięstwie „wolności”, jest możliwość decydowania o sobie: „,bo można umrzeć pod płotem / lub ojcem być Dioklecjana" — zostać obcym na zawsze, nigdy nie odnaleźć swojego miejsca lub zaakceptować wygnanie i stać się człowiekiem wolnym - „wyzwoleńcem", dać wolność sobie i przyszłość swoim potomkom.

$\mathrm{Na}$ zasadzie kontrastu pomiędzy Ameryką a Polską skonstruowany jest także wiersz o jednoznacznym tytule Emigracja (IS, s. 10):

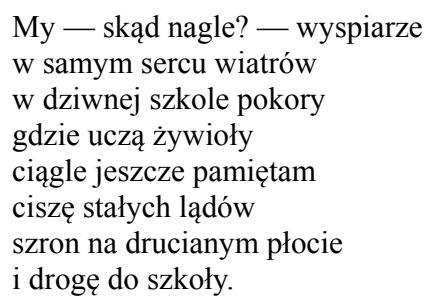

Zbiorowe „my” odsyła do doświadczenia wspólnego, nie zaś indywidualnego, pojedynczego, uniwersalizując to poetyckie wyznanie ${ }^{18}$. Wygnańcy zmagają się z trudnymi doświadczeniami, walczą z żywiołami - przeciwnościami. Kluczową rolę w tym poetyckim obrazie odgrywa wiatr, nieposkromiony żywioł symbolizujący los, który nimi targa. Na skutek żywiołu nie mogą przewidzieć tego, co ma ich spotkać. Powoduje to przeświadczenie, że Ameryka jest tylko przystankiem, wyspą, a nie stałym lądem w dalszej wędrówce: „przejazdem przez kontynent / i przez ten wiatr przejazdem” (Brooklińska kancona, OIO, s. 51), dlatego nie trzeba się tu osiedlać się na stałe, zadomawiać.

Cierpienie wygnanej w obcym kraju, nazywanym bardzo wymownie: „Kontynentem / pełnym świeżych ran" (Pożegnanie Anglii, OIO, s. 50), wywołuje bezradność. Brak pomocy ze strony otoczenia, które zamyka się w swoich domach, ,przyłbice zsunięte na czoła”, Na kamiennej łodzi (WSL, s. 32). Taka postawa obojętności społeczeństwa przypomina zaś wydarzenia marcowe:

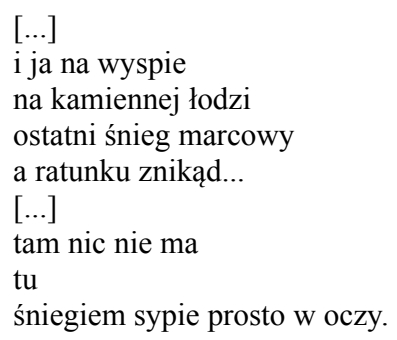

„Tu”, czyli w Ameryce, nikt nie oferuje wsparcia, osoba mówiąca w wierszu jest skazana na samotność w obliczu problemów. W Polsce natomiast „nic nie ma”. Owo „nic” symbolizuje tak wiele. Tam nie ma dla niej przyszłości, życia, perspektyw, nie ma jej, przyjaciół, rodziny. Kraj dzieciństwa zostaje odrzucony jako miejsce naznaczone bólem.

${ }^{18}$ Zob.: M. Karpińska, Poety emigracyjnego zmagania z biografia (na przykładzie twórczości Anny Frajlich), Akcent 2005 nr 3, s. 84. 
Świadomość wyobcowania powoduje, że wygnana czuje się w nowym otoczeniu kimś innym, oddzielnym. Na tym etapie nie zauważa pozytywnych aspektów emigracji. Jest to dla niej okres bardzo bolesny, cechujący się różnorodnością uczuć: wstydem z powodu swojego losu i odmienności, pozbawioną sentymentalizmu tęsknotą za Polską $^{19}$ oraz odrzuceniem jej jako swojej ojczyzny, wreszcie - chęcią zadomowienia i strachem przed tym, bezradnością. Cały ten wachlarz odczuć powoduje zagubienie i kryzys osobowości wygnanej.

Kolejnym etapem w życiu bohaterki wierszy Anny Frajlich jest powolne przyzwyczajanie się do nowego miejsca i warunków życia, które, za badaczem literatury emigracyjnej, nazwać można „oswajaniem”20. W jej utworach, początkowo bardzo nieśmiało, pojawiają się sygnały możliwości zaakceptowania emigracji: „Śpij syneczku / i podróżni / pokochają swe bezdroża. Śpij” (Jesienna kotysanka, ABW, s. 29). Matka - emigrantka tymi słowami usypia, uspokaja nie tylko swoje dziecko, lecz przede wszystkim siebie samą $^{21}$. Sen da mu wytchnienie, ochroni przed złem, przyczajonym w mrokach nocy. Dla niej takim snem - uspokojeniem będzie stan afirmacji wypędzenia. Wyrażona w przytoczonych wersach nadzieja zdaje się zapowiadać bardziej dobitną deklarację: ,jest droga / i nie zawrócę” (Rymy najprostsze, JWD, s. 16). Jest to świadectwo chęci zmierzenia się z doświadczeniem emigracji.

W życiu wygnanej ogromną rolę odgrywają żywioły ${ }^{22}$. Symbolizują one zmienne koleje losu, warunki, które są od niej niezależne, istnieją mimo jej woli. One to wielekroć są jej nieprzychylne, tak że musi z nimi walczyć. Powoli jednak godzi się na ingerencje tych sił w swoje życie. Wynika to raczej z bezsilności i niemocy niż świadomego przyzwolenia i chęci:

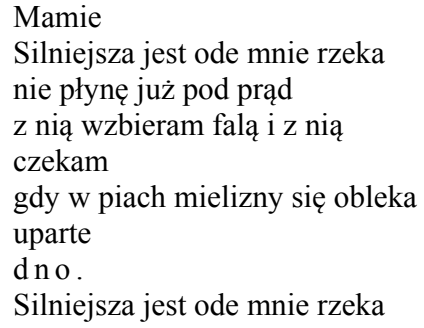

(IS, s. 28)

Walka z rzeczywistością, losem wygnańczym, okazuje się nieskuteczna, dlatego należy zdać się na czas, który może przykryć „uparte dno” — po raz kolejny odwrócić sytuację na korzyść pokrzywdzonej. Wiersz ten jest świadectwem nadziei na zmianę. Bardzo mocno ten wątek rozwijany jest w liryku List z Nowego Jorku (ABW, s. 52). Ma on, jak wskazuje sam tytuł, formę epistolarną, widnieje pod nim dokładna data, wskazująca na upływ pięciu lat od wyjazdu Anny Frajlich z Polski. Ten bardzo wy-

19 Zob.: Obserwator, Anna Frajlich w POSK-u, Dziennik Polski i Dziennik Żołnierza 16.12.1978, s. 12 .

${ }^{20}$ W. Ligęza, Lampa w oknie, Rzeczpospolita $2000 \mathrm{nr}$ 179, s. E5.

${ }^{21}$ Zob.: R. Grol, Erotyka i wygnanie. Poezja Anny Frajlich, przeł T. Kunz [w:] Życie w przekładzie, red. H. Stephan, Kraków 2001, s. 103. Dramatyzm tułaczego losu w tym wierszu jest złagodzony spokojną konwencją gatunku; zob.: A. Węgrzyniakowa, Życie w podróży, s. 302.

${ }^{22}$ Na szczególną rolę żywiołów zwraca uwagę M. E. Cybulska w artykule Uwikłana wśród żywiołów (O liryce Anny Frajlich), Przegląd Polski 04-10.11.1981, s. 5A-7A. 
mowny utwór porusza kilka poważnych problemów, dlatego przytoczony został w całości:

\author{
„nie przeziębi najgorszy mróz, \\ jeżeli kto ma zapach róż, \\ owinął go w słomę zbóż, \\ a na wiosnę go odwiążą \\ i sam odkwitnie" \\ Stanisław Wyspiański
}

Nie ma cię tam gdzie byłeś

i gdzie jesteś - nie ma

jeszcze $\mathrm{z}$ lękiem obolałych godzin

wiesz? - listopad

a róże wciąż kwitną w ogrodzie

w tym największym z miast świata

a słomy na chochoły?

jak mróz? - nie przesyłaj

niech je wiatr oceanu

miłośnie otuli

niech poznają

zwątpienie

..............................

Napiszę

jak odkwitną.

\title{
[12 XI 1974]
}

Motto utworu to słowa Racheli z Wesela Wyspiańskiego, wypowiedziane w czasie rozmowy z poetą. Rachela jest Żydówką, ma artystyczną duszę, postrzega wesele jako inspirujące doświadczenie poetyckie i literacki temat. Uważa, że chochoły są symbolem uśpienia natury, która jednak wiosną budzi się do życia. Osoba mówiąca w wierszu to emigrantka, także Żydówka, mieszkająca „w tym największym z miast świata” Nowym Jorku, w którym róże nie potrzebują chochołów: pomimo listopada nadal kwitną, gdyż klimat jest dla nich łagodniejszy. Róże symbolizują tu piękne życie. Chochoły to także, idąc tropem Wesela, symbol marazmu i uśpienia Polski, którego w innym znaczeniu niż to, do którego odwoływał się Wyspiański, mogła doświadczyć kobieta. $\mathrm{Z}$ powodu antysemityzmu, głęboko zakorzenionych stereotypów, zamkniętych umysłów Polaków, musiała opuścić ten kraj. Tym Ameryka różni się od Polski, że nie ma w niej chochołów i nie potrzeba ich, gdyż wiatr róże tylko „miłośnie otuli”.

Jest to wiersz, który naśladuje listy, pisane do Polski przez wygnańców. A ponieważ w kraju działała cenzura i każdy z nich był sprawdzany, nadawczyni posługuje się silnie zmetaforyzowanym językiem ezopowym. W trakcie długiej podróży listu odbiorca może się przemieścić, znaleźć gdzie indziej i nigdy go nie przeczyta: „Nie ma cię tam gdzie byłeś / i gdzie jesteś — nie ma”. Może on być pisany do każdego, kto został w kraju, ale także nie mieć konkretnego odbiorcy. Tekst ten jest bardzo osobisty, ale poprzez uogólnienia wskazuje na powszechny motyw wysyłania listów i paczek z wygnania.

Życie emigranckie jest bardzo trudne i wymagające. Osoba mówiąca jednak powoli przyzwyczaja się do tego. Budzi się w niej nadzieja, wie, że kiedyś „odkwitnie” tak jak róża. Wcześniej zupełnie obca, przestrzeń Ameryki zaczyna docierać do niej podwójnie. Nadal stanowi zagrożenie i nie jest do końca bezpieczna, jednak emigrantka 
podejmuje próby jej oswojenia. W tym celu zestawia dobrze znany sobie krajobraz i naturę polską z tą nową - amerykańskąą.

Ameryka jest dla kobiety miejscem niezrozumiałym i pełnym skrajności, a zarazem tajemniczym, intrygującym, a przez to pociągającym. Wygnani nie czują się tu jak w baśni, co podkreśla ironiczna fraza: ,i w naszej wielkomiejskiej baśni tysiąc pierwszą noc" ( $W$ splataniu znaków, OIO, s. 44). Życie tu jest pełne dziwnych wydarzeń, które nie zawsze są dla nich zrozumiałe: „w splątaniu znaków kto wie jaki sens odczytać”. To powoduje rozmyślania, które kończy wniosek, że „— niepewność pośród mroku jak głód prowadzi nas". Jest to miasto, gdzie każdy może zaczynać swoje życie od nowa: „zdetronizowani króle / i cesarzowe bez cesarstwa / wyprowadzają psa na spacer" (Ergo sumus, KL, s. 7). Nieważne jest pochodzenie, tu każdy może znaleźć schronienie, wytchnienie, symbolicznie przysiąść na chwilę nad lampką wina. Dlatego możliwe staje się zadomowienie w tym miejscu:

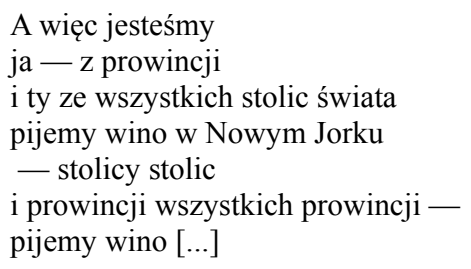

To miejsce pełne sztuki (,w galerii wiszą trzy Chagalle”), przesiąknięte poezją („Tu poeci / w dwustu językach dla nikogo / piszą swe wiersze jak szaleni”), która tworzy nierzeczywisty wizerunek tego miejsca. Realne są natomiast wielkie kontrasty, gdyż jest to miasto:

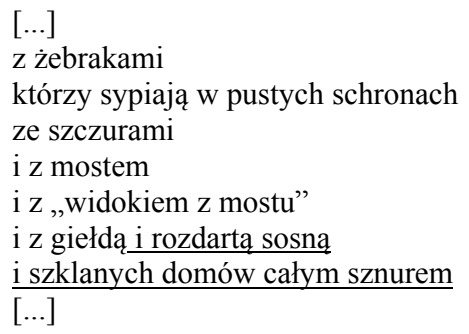

${ }^{23}$ Ten zabieg artystyczny, podkreślający wygnanie, jest szczególnie obecny w tomie Indian Summer, którego sam tytuł stanowi połączenie Polski i Ameryki. Określenie „Indian Summer” to polskie babie lato, złota polska jesień, koniec lata, chociaż przeżywane już nie w Polsce a w Ameryce, stąd określenie pochodzące $\mathrm{z}$ języka angielskiego. Według Wygodzkiego tom ten pokazuje bardzo wyraźnie tożsamość poetki. W liście do niej z dnia 30 listopada 1982 r. pisze tak: „Odkryłem chyba tajemnicę Twoich wierszy (nie użyję ani jednego przymiotnika): mieszkasz w Brooklynie, przeżywasz, a raczej uczestniczysz w jakimś Indian Summer, ale Ty przecież z Polski JESZCZE nie wyjechałaś"; cyt. za: K. Adamczyk, Antynostalgia i nostalgia. Rzecz o wygnaniu, [w:] tegoż, Doświadczenia polsko-żydowskie w literaturze emigracyjnej (19391980), Kraków 2008, s. 166. O tytule tomu zob.: M. Peretz, Indian Summer Anny Frajlich, Przegląd Polski 28.10-03.11. 1982, s. 7; W. Gniatczyński, „Audycja o nowym tomiku wierszy Anny Frajlich”, mps., Radio „Wolna Europa” [brak daty emisji], s. 2-3; F. Śmieja, Do trzech razy sztuka, Związkowiec $1983 \mathrm{nr}$ 6; A. Węgrzyniakowa, Po Marcu, [w:] Literatura emigracyjna 1939-1989, red. J. Garliński, Z. Jagodziński, J. Olejniczak, I. Opacki, t. 1, Katowice 1994, s. 147. 
Wyróżnione wersy pokazują wewnętrzne sprzeczności. Odwołują się one do symboliki dzieł Stefana Żeromskiego, Ludzi bezdomnych i Przedwiośnia. „Rozdarta sosna” to symbol podzielenia wewnętrznego, bólu spowodowanego koniecznością wyboru, który zmieni całe życie, niemożnością podjęcia jednoznacznie dobrej decyzji. W przypadku wygnanej jest to tęsknota za ojczyzną, cierpienie spowodowane ucieczką z niej. Egzystencja w nowym miejscu nie jest dla niej wolnym wyborem, lecz koniecznością, jednak ona wie, że nie mogła pozostać w Polsce i to powoduje owo rozdarcie. Jednocześnie Ameryka to kraj „szklanych domów” w znaczeniu dosłownym - wieżowców, metaforycznie zaś - to kraina utopii. Budowle te symbolizują bardzo nowoczesną cywilizację, opartą na rozwoju technologii, ułatwiającej ludziom życie. Budynki i mieszkania są czyste, niedrogie, ale i kruche. W powieści Żeromskiego Polska ma być krajem „szklanych domów”, jednak jest to tylko marzenie bohatera. W cytowanym wierszu, w Ameryce znajdują się takie domy, jednak to tylko daje złudne wrażenie, że to kraj idealny, szczęśliwy. Udowadniają to przywołane wcześniej kontrasty. Wszystko, co dostrzega podmiot mówiący, jest bardzo ulotne, nietrwałe jak balon, może wzlecieć w powietrze, zniknąć na zawsze. Wydaje się jednak, że ta swoista utopijność jest bardzo pociągająca i nikt nie chce jej zniszczyć: „nie ma takiego śmiałka / który / by pstryknął”. Także same tytuły przywoływanych dzieł Żeromskiego w kontekście biografii poetki mogą być znaczące. „Przedwiośnie” jako znak odrodzenia, budzenia się do życia, to nadzieja emigrantki na zmianę swojego losu, zaś „ludzie bezdomni” to aktualne jej położenie. Kolejny liryk potęguje wrażenie bezdomności w znaczeniu nieposiadania ojczyzny. Ameryka to Tylko ziemia (TZ, s. 5):

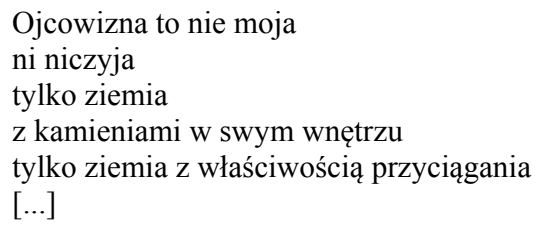

Ziemia ta jest charakteryzowana poprzez cechy, pochodzące z różnych porządków. Jest to opis bardzo surowy, quasi-naukowy, cechuje go podejście rozumowe, a nie uczuciowe. To tylko gleba, zawierająca kamienie ${ }^{24}$, to także ciało przyciągające inne ciała. Jednak ,newtonowska siła ciężkości stosuje się też do ludzkiego serca, nieobojętnego na to przyciąganie" ${ }^{25}$. Opisywana tu Ameryka to miejsce podobne do innych, z jedną różnicą — nie jest ona niczyją ojcowizną ${ }^{26}$, ponieważ każdy jest tu przybyszem, wygnańcem. Jest to cecha, która pomaga w zaakceptowaniu tej przestrzeni i umożliwiająca stopniowe oswajanie się z obcą ziemią: „,chodzę po niej / czasem dotknę jej ręką”. Ostatni gest jest bardzo wymowny. Nie jest to całowanie ziemi, które świadczy o miłości, przywiązaniu, więzi, ale „dotykanie” - gest przyzwyczajania się, powolnego oswajania, podobny do obłaskawiania, ujarzmiania obcego zwierzęcia. Rezultatem tego procesu jest dostrzeżenie piękna pejzażu, który jest identyczny ze znanym z ojczystego kraju: ,ale w zimie zamarza jezioro / i spadają w śnieg szyszki z sosen”, „,nagie słońce zachodzi za szosę”. To zestawienie na zasadzie podobieństwa obu krajobrazów jest znamienne dla wierszy

\footnotetext{
${ }^{24}$ Kamienie mogą być aluzją autobiograficzną, gdyż dopiero w Ameryce Frajlich zobaczyła grób jednego z członków swojej rodziny.

${ }^{25}$ N. Gross, Miejsce na ziemi, Nowiny Kurier 17.09.2001, s. 10.

${ }^{26}$ Henryk Grynberg ze względu na cechę bycia „ojcowizną niczyją” interpretuje „ziemię” bardzo uniwersalnie, z doczesnym obcowaniem; zob.: H. Grynberg, Tylko ziemia, poezja i miłość, Wiadomości $1979 \mathrm{nr} 44$ (1753), s. 2.
} 
z okresu adaptacji (wydanych w latach 1982-1994). Pomaga w zrozumieniu przestrzeni, która wcześniej wydawała się tak różna od polskiej, a przez to obca i odrzucana.

Magnetyczna siła Nowego Jorku oraz ogromna chęć przynależności, odbudowy swojego domu, powoduje u wygnanej podjęcie próby zakorzenienia. Szczególnie jasno przedstawiają ją wiersze, posługujące się metaforyką, zaczerpniętą ze świata natury, a zwłaszcza metaforą drzewa, symbolu trwałości, zapuszczenia korzenieni, dojrzewania, bycia głęboko w ziemi, zarazem zaś patrzenia w niebo. To także znak godnego przemijania i odradzania się na nowo oraz swobodnego poddawania się siłom natury (Indian Summer, IS, s. 32). Te cechy powodują, że drzewo staje się symbolem wygnanej, która sama jest jak przesadzone drzewo: aby żyć, musi powtórnie „korzeniem wgryźć się” ( $\mathrm{Na}$ ulice w Brooklynie, IS, s. 21). Emigrantka jest świadoma, że Ameryka nie jest idealnym do tego miejscem: „nie ma zaułków / ni zakamarków / schronień na życie”, więc „nie tu / osiadać / gniazda zakładać”, ale nie mając wyboru, podejmuje próbę. Pragnie tylko „raz się odwrócić / spojrzeć do tyłu". Werset ten jednoznacznie odsyła do biblijnej historii żony Lota, która, lekceważąc boski nakaz, odwróciła się, by spojrzeć na zagładę Sodomy, i zamieniła się w słup soli ${ }^{27}$. Bohaterka wyraża tylko pragnienie, nie czyni zaś gestu spoglądania za siebie, który może przynieść jej śmierć. Nie jest to wyraz chęci zapomnienia o przeszłości, lecz raczej konieczność wyzwolenia się od jej negatywnego wpływu, ciągłego życia minionymi zdarzeniami. Zauważa ona coraz wyraźniej piękno miasta i jego cechy, pomocne w osiedleniu się, choć zarazem jest pełna obaw i wątpliwości. Nadal jest tutaj inną, obserwuje Nowy Jork z zewnątrz. Dystans do tego miejsca umożliwia trzeźwe osądzenie, że jest ono zarazem piękne i niebezpieczne.

\section{Ameryka — nowa Ziemia Obiecana?}

Przestrzeń amerykańska staje się z czasem w poezji Anny Frajlich przedmiotem zachwytu i uwielbienia. Zauważa ona walory miasta, jego szczególną architekturę, która wcześniej była dla niej zupełnie obca, kontrastowana z architekturą polską. Po upływie czasu widzi w nim harmonię, zespolenie natury i cywilizacji (Panorama Manhattanu (IS, s. 29). Akcentowana jedność wydaje się szczególnie ważna ze względu na zagrażające żywioły. Teraz są one uśpione, uspokojone, wiatr ugrzązł w „kamiennych żaglach" i nie ma już władzy miotania życiem kobiety. Co więcej, jest to przestrzeń pełna mostów, łączących ze sobą wyspę - Nowy Jork, z kontynentem (perspektywa horyzontalna), natomiast sama architektura łączy niebo z ziemią (perspektywa wertykalna). Miasto zostaje przedstawione jako idealne, doskonałe także do osiedlenia. Akcentuje to poniższy wiersz:

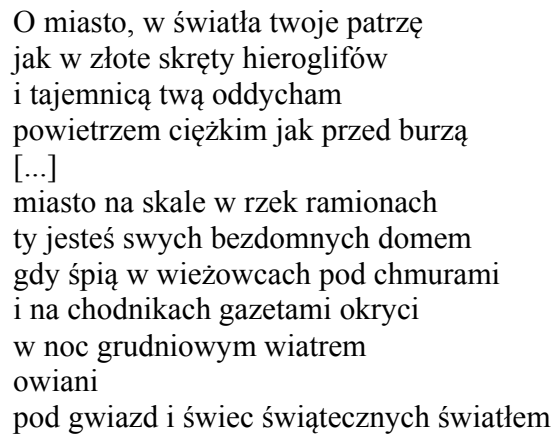

${ }^{27}$ Zob.: Rdz 19,26. 


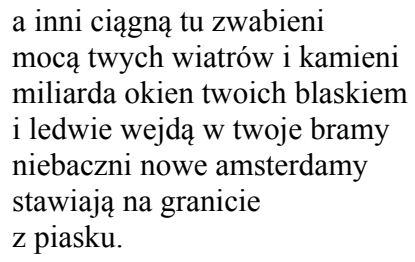

***O miasto, w światta twoje patrze (BDATW, s. 46)

Kolejne strofy przytaczają poszczególne cechy miasta, związane z jego pejzażem. Jest ono pełne blasku, tajemnicy, piękna. Najważniejszy jednak okazuje się obraz miasta jako miejsca schronienia, domu dla tych, którzy go już nie mają. „Bezdomność” nie dotyczy tylko tych, którzy nie posiadają miejsca do zamieszkania, lecz także tych, którzy żyją w wieżowcach, ale są zagubieni lub wygnani, dlatego w innym wierszu Nowy Jork nazywany jest „ojczyzną wszystkich zbłąkanych” (Nowy Jork, listopad i róża, OIO, s. 26).

W Ameryce zachwyca nie tylko przestrzeń. Jest to miejsce przyjazne, akceptujące przybyszów, pełne różnic kulturowych i dzięki temu otwarte na inność, nieprzekreślające jej. Na obecność wielokulturowości wskazuje wiersz o Wielkim Piątku, Wielkanoc w Nowym Jorku (ZSMW, s. 31-32):

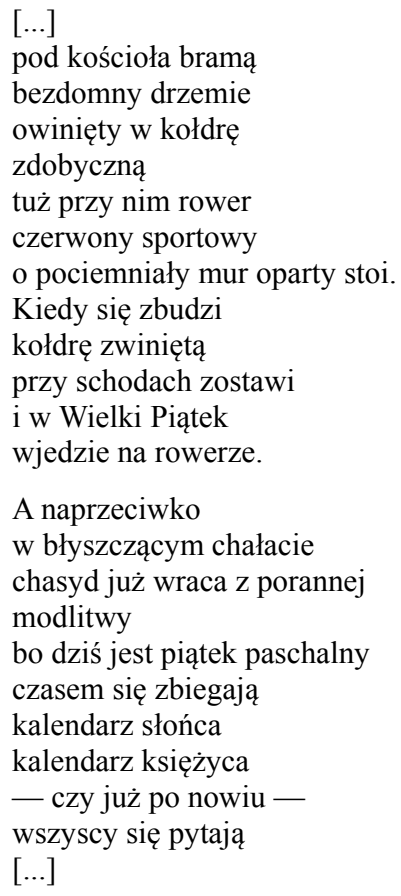

[Wielkanoc 2000]

Nowy Jork zostaje przedstawiony jako miasto, w którym obok siebie istnieją dwie religie: chrześcijańska — „kalendarz słońca” i judaistyczna — „kalendarz księżyca”. Są one wobec siebie równe, czasami nawet mogą się ze sobą spotkać i nie kolidować. Tu, w Ameryce, nie ma prześladowań na tle religijnym, antysemityzmu, który był przyczyną wygnania autorki. Multikulturowość Nowego Jorku w tej poezji jest po- 
strzegana pozytywnie, jako część miasta, jego kultury i tradycji, jako cecha umożliwiająca wypędzonej zaaprobowanie, a nawet pokochanie tego miejsca. Wszystko to spaja bardzo sugestywny obraz: bezdomny może okazać się Mesjaszem.

Wskazana powyżej specyfika Ameryki wywołuje w bohaterce pozytywne uczucia, które z kolei przeradzają się $\mathrm{w}$ akceptację, budującą w niej poczucie przynależności. Stara się ona zadomowić w Nowym Jorku. Jest to proces powolny, który charakteryzują wątpliwości, zadawanie pytań. Początki tej ewolucji zwiastują wersy liryku Tematy (WSL, s. 36), przywołujące metaforę ptaków: ,[...] przyleciały już północne ptaki / kiedy dzień się wydłuży odlecą / z dwojga ojczyzn w dwojakie wygnanie".

Późniejsze obrazy wykluczają jednak wzmiankowaną możliwość posiadania dwóch ojczyzn. Najpełniej ów stan przedstawiają teksty zestawiające „tu” i „tam”, „nowe” i „stare”. Jednym z nich jest wiersz Ogrody i domy (WSL, s. 23-24), w którym wygnana thumaczy sama sobie, gdzie jest jej dom:

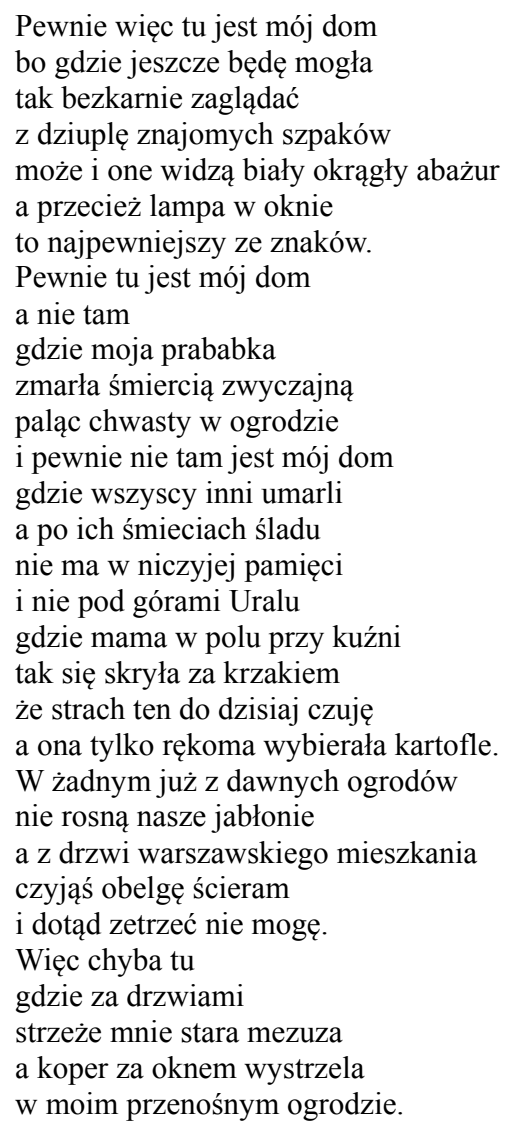

Przytoczony tekst został osnuty na kanwie historii życia wygnanej. Poetka wylicza kolejne wypędzenia, wszystkie ogrody i domy, w których przyszło jej żyć. Przedstawienie nowego domu możliwe jest poprzez zestawienie go $z$ dawnym ${ }^{28}$. Opozycja ,tu” — „tam” nie tylko wyraża kontrast czasowy i przestrzenny, to także metafora odmienności kultur i w ogóle zróżnicowania życia. Dawne domy naznaczone są cierpieniem,

${ }^{28}$ W. Ligęza, Jerozolima i Babilon. Miasta poetów emigracyjnych, s. 16. 
śmiercią (Lwów), głodem, strachem (Ural) oraz prześladowaniem o charakterze antysemickim (Warszawa). Bezpiecznym domem okazuje się ostatecznie Nowy Jork, który jest zgoła inny, gdyż daje spokój, światło oraz wytchnienie od traumy przeszłości. Jest przede wszystkim miejscem, gdzie wygnana może być Żydówką i otwarcie o tym mówić. Tutaj sama naznacza swoje mieszkanie (nie tak, jak zostało naznaczone to warszawskie $^{29}$ ) mezuzą, wskazującą na jej tożsamość. Wykonuje tę czynność, ponieważ czuje się wolna i wie, że nic jej za to nie grozi. Dalej, chociaż posadzony przez nią ogród jest mały i przenośny, nie przypomina innych ogrodów, wydaje się idealny, stając się namiastką Ogrodu Rajskiego.

Warto przyjrzeć się także paralelnemu ze względu na wymowę tekstowi, również budowanemu na zasadzie kontrastu, choć bardziej ogólnego, doprowadzającego do jednoznacznej konkluzji, że:

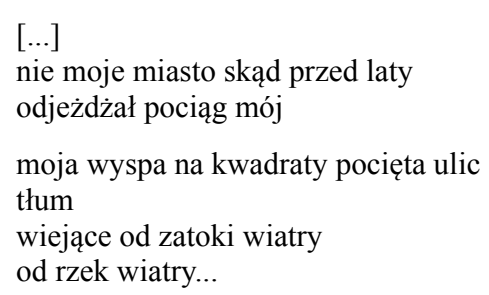

*** Nie mój jest zamek i komnaty (KL, s. 32)

Na szczególną uwagę zasługuje użyty tu zaimek dzierżawczy „moje”, „moja”, wskazujący na posiadanie, przynależność. W takiej samej funkcji pojawia się on w wierszu Nowy Jork (ŁJJJP, s. 15), w słowach określających związek Nowego Jorku i wygnanej: „To miasto jest moje / i ja jestem jego”. Kobieta, chociaż straciła dom przed laty, teraz zyskuje nowy, a strata zaczyna być waloryzowana pozytywnie. Miasto to, mimo wszelkich zalet, ciągle owiewane jest przez wiatry, które jak we wcześniejszych wierszach symbolizują trudności, przeciwności losu. Te jednak zdają się wpisane w życie i z czasem podmiot liryczny przyzwyczaja się do nich. Oswojenie i przywykanie do przeszkód oraz niepowodzeń ukazuje wiersz Tu jestem (WSL, s. 25). Opisywana w nim przestrzeń muszli ślimaka, chociaż może wydawać się ciasna i niewygodna, dla wygnanej stanowi dokładanie dopasowany dom. Między muszlą a domownikiem zachodzi niesamowity związek przynależności i przylegania, tak że nie jest już ważne, „Czy wybór to czy nie-wybóo”. Posiadanie takiego miejsca powoduje, że emigrantka staje się silniejsza, odporna na doświadczenia, twarda jak orzech. Wygnana, niegdyś określająca siebie słowami ,jestem oddzielna", teraz identyfikuje się ze swoim miejscem wygnania poprzez zwrot: „tu jestem”. Czasownik pozostał ten sam, natomiast przymiotnik, sugerujący odrębność, przynależność do „tam”, został zastąpiony przysłówkiem „tu”. Zmiana ta pokazuje metamorfozę bohaterki, przeobrażenie sposobu postrzegania siebie $\mathrm{w}$ odniesieniu do przestrzeni oraz akceptację jej. Afirmacja obcej dotychczas przestrzeni może z kolei sugerować zakończenie doświadczenia wygnania. W twórczości Anny Frajlich dochodzi do pewnego przesunięcia — od odrzucenia przestrzeni do jej akceptacji. Podobnie rzecz ma się z samym wygnaniem jako konkretną historią i stanem umysłu. Kobieta wypędzona reorganizuje swój świat. Rozpoczyna

${ }^{29} 1$ stycznia 1969 r. Anna Frajlich wraz ze swoim małżonkiem — Władysławem Zającem wyszli na dwie godziny z domu. Po powrocie na drzwiach ich mieszkania widniał napis: „Tu mieszka chołota - Żydzi”; zob.: A. Frajlich, Marzec zacząt się w czerwcu, Midrasz 1998 nr 3, s. 7. 
nową egzystencję, która cechuje się poczuciem zysku, a nie, jak wcześniej, wyłącznie straty; to zgoda na wydarzenia z przeszłości oraz otwartość na przyszłość. Rozumie, że spełnienie zawdzięcza konieczności emigracji. Dostrzega, że ból może przynosić korzyści, budować, a nie tylko niszczyć życie. Obrazuje to wiersz Zlota gałaź (WSL, s. 56), w którym poetka posługuje się metaforą jemioły jako obrazem sytuacji wygnania. Płaczące liście przemieniają się w „pozłocistą miotłę”, w tytułową „złotą gałąź”, w coś pięknego i przynoszącego owoce: ,jej łże-liście pęcznieją od soków... / Uderzają o grudę żołędzie". Jest to piękna apologia cierpienia i jego roli w życiu samej emigrantki. Tekst ten wpisuje się w szerszą grupę utworów, związanych $\mathrm{z}$ zagadnieniem akceptacji i posługujących się symboliką drzewa. Dla porównania warto przytoczyć Wiersz noworoczny (BDATW, s. 142), który jest lirykiem pełnym miłości, spełnienia, a zarazem pewnego niedowierzania w odzyskany spokój. Wrażenie wewnętrznej harmonii emigrantki potęguje zrównoważony ton wypowiedzi, przyjazna atmosfera i przestrzeń. Osoba mówiąca powoli wprowadza w swój świat. Zaczyna od czasownika „lubię", który nie opisuje, lecz wyraża jej czuły stosunek do niego. Jest to nocne, a więc uspokojone, wyciszone wnętrze „domu”. To przestrzeń nie tylko budynku, ale umysłu, całej egzystencji wygnańców. Kobieta, obserwując niezmącony sen mężczyzny, widzi, że „znaleźli miejsce”, które jest „tu”. Dziwi się temu, być może nigdy nie spodziewała się, że to uczucie kiedyś nastąpi, bo oni „to tylko / przeszczep”. Ten jednak okazał się udany i dzięki temu teraz znów powracają do życia, rozpoczynają jego nowy etap, który nadal czerpie „z tych / innych / niezrozumiałych / poplątanych / korzeni” przeszłości, tożsamości polsko-żydowskiej.

Opanowany ton wypowiedzi cechuje również wiersz Ten powiew (WSL, s. 58), pokazujący, jak akceptacja trudności, losu, który przygnał ją na tę wyspę, wpływa na podmiot liryczny:

$$
\begin{aligned}
& {[\ldots]} \\
& \text { ten powiew } \\
& {[\ldots]} \\
& \text { ciało moje opłukuje } \\
& \text { i w tętnicach tętno } \\
& \text { odnajduje swój rytm } \\
& \text { u-spo-ko-jo-ny. }
\end{aligned}
$$

Zmianie ulega całe ciało, którego nowy rytm jest spokojny, równomierny, co potwierdza specyficzny zapis ostatniego wyrazu. Automatycznie, dzięki zmianie tętna, uspokaja się serce - narząd i symboliczne siedlisko czuć, emocji. Poddanie się żywiołom prowadzi do innego spojrzenia na swoje życie: „i wciągam w płuca spokój / z uśmiechem bezwstydnym" (Wina, KL, 5). Wiersz przedstawia obrazy szalejących żywiołów, którym opiera się osoba mówiąca w wierszu. Ona jak źdźbło stoi nieruchoma „w samym oku cyklonu”. Jest spokojna i odważna, chociaż taki stan jest dla niej nowością: „Z niedowierzaniem ręce odrywam / od twarzy”. Samo zakończenie ,... kto jest bez winy pierwszy / niech rzuci kamieniem" nawiązuje do nowotestamentowej sceny, kiedy Jezus wybacza grzechy cudzołożnicy, którą wszyscy potępili i skazali na śmierć (J 8, 1-11). Wskazuje tym samym na nieosądzanie przez wygnaną innych, także tych, którzy szczególnie zasługiwaliby na potępienie, bo skazali ją na uchodźstwo - życie wśród żywiołów. Ona skazuje ich na Sąd Boży, godząc się tym samym ze swoją historią.

Doświadczenie wypędzenia prowadzi do zmiany osobowości. Dopiero po zakończeniu buntu, zmagania się z sytuacją emigracji, gdy wygnaniec na nowo buduje swój wizerunek, może okazać się, że jego tożsamość uległa rozszerzeniu. O tym traktuje wiersz O tożsamości (w duchu imitacji pod Biatoszewskiego) (WSL, s. 53): 


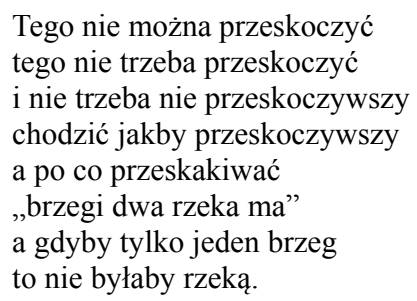

Występujące już $w$ tytule nawiązanie do polskiego poety lingwistycznego oraz cytat, pochodzący z piosenki Sławy Przybylskiej Powiedziała mama mi, wskazują na polską kulturę, a tym samym polską część tożsamości poetki. Stanowi ona jeden brzeg, ten przedwygnaniowy, drugi natomiast to tożsamość zbudowana po wypędzeniu, czyli amerykańska, i pobudzona przez wygnanie - żydowska. Te części osobowości składają się na jedną, polsko-żydowsko-amerykańską ${ }^{30}$, która dopiero w takim połączeniu stanowi kompletną tożsamość, „a gdyby tylko jeden brzeg / to nie byłaby rzeką”. $\mathrm{Z}$ tego powodu wygnana nie chce wybierać żadnej z nich: „tego nie trzeba przeskoczyć”, bo „po co przeskakiwać”, gdy można żyć, godząc ze sobą tak różne bieguny własnej jaźni. Nie jest to zapis rezygnacji czy zmuszania się do wyborów, których przecież nie sposób dokonać (,tego nie można przeskoczyć”), ale świadectwa dojrzewania do pełnej akceptacji siebie i swojego życia. To wyraz nowego zdefiniowanie siebie jako Żydówki, Polki i Amerykanki. Poetka charakteryzuje się w tym wierszu „zintegrowanym poczuciem tożsamości” ${ }^{\text {”1 }}$.

Mimo że bohaterka tych utworów zadomowiła się już w Ameryce, czuje więź z tym miejscem i nazywa je swoją ojczyzną, przebudowała swoją tożsamość, jak wskazują poniższe teksty, nie zakończyła tułaczki, nie przestaje być wypędzoną. Ten przedziwny status dobrze obrazuje tekst Tanatos $i$ eros (BDATW, s. 140), który wskazuje na akceptację losu, Ameryki, ale zarazem niemożliwość pokochania tej ziemi do końca, ostatecznie:

\author{
Umrę tam \\ gdzie mnie posiało \\ gdzie rzucił los \\ ziemia wchłonie moje ciało \\ ziemię wchłonę swoim ciałem \\ tak jak gdybym pokochała... \\ Tak. \\ Jak gdybym pokochała.
}

Życie jako wieczną wędrówkę ukazuje cykl wierszy $Z$ jakiego portu płyna do jakiego (ZSMW, s. 13-19). Ostatni z nich rozpoczyna się łacińską sentencją: „Navigare necesse est, vivere non est necesse". Została ona wypowiedziana przez Marka Antoniusza do żeglarzy, którzy mieli wypłynąć ze zbożem w czasie sztormu z Egiptu do głodującego Rzymu. Przywołane motto w historii kultury przerodziło się w symbol ruchu, przemieszczania się ważniejszego od samego życia. Osoba mówiąca uświadamia sobie, że: „Wszystko jest karą / za to że myślałam / że już dotarłam” Z jakiego portu plyna do

${ }^{30}$ Szata graficzna tomu $W$ słońcu listopada, z którego pochodzi ów wiersz, potęguje wrażenie zespolenia żydowskości z amerykańskością: grafiki Bartka Małysy (Ikar, Statua i Sanskryt) są ,inspirowane kulturą i architekturą amerykańską oraz literaturą starohebrajską"; S. J. Żurek, Sam na sam z poezja, Akcent 2003 nr 4, s. 166.

${ }^{31}$ R. Grol, Erotyka $i$ wygnanie, s. 110. 
jakiego (ZSMW, s. 19). Jej wygnanie nie ma więc końca. Znowu, mimo zadomowienia, nazywa Amerykę ,innym krajem”, tam „za karę” liczy „,barki na rzece”, których nie można zliczyć i dowiedzieć się, ,z jakiego portu / płyną do jakiego”. One przypominają jej skąd przywędrowała. Płynące łodzie mogą stanowić także symbol powrotu do kraju dzieciństwa. Chociaż poetka nie jest w stanie przewidzieć swojego losu, przekalkulować go, policzyć, wie jednak, skąd wypłynęła jej łódź. Ten fakt przypomina jej Polskę i uzmysławia, że na zawsze pozostanie osobą podróżującą. Wygnanie w tym wierszu staje się paradygmatem całego życia człowieka, od narodzin aż do śmierci.

Bardzo subtelnie sugeruje to także liryk Znów szuka mnie wiatr (ZSMW, s. 35). Opisywany jest w nim żywioł wiatru — wędrówki, który nieustannie „szuka” emigrantki, chce przegnać ją dalej, być może do Polski. Ona ciągle czuje konsekwencje działania oraz jego siłę, z którą postanawia się zmierzyć: ,„przełamało się na pół / istnienie / i tam gdzie mnie nie posiało / do słońca wyciągam gałęzie / i plecy wystawiam na grad". Wiatr, w ostatnich strofach, jest tym, który ,z czarnych chmur strąca nuty / na requiem". Obraz ten wiąże się z przemijaniem, śmiercią, która będzie wytchnieniem, requiem — odpoczynkiem. Teraz bowiem życie jest naznaczone bólem, który czasem może być uśpiony, zasuszony tak jak róże, „co stoją dla ozdoby”, ale wystarczy jeden impuls, „lipcowa noc”, przypomnienie przeszłości, a wtedy: ,jedna [...] / płatki swe otwiera / i ból obnaża / — ziarno swej choroby?" (Z jakiego portu płyna do jakiego (ZSMW, s. 16). Kwiaty te symbolizują miłość oraz cierpienie, które jest w nich i w niej ukryte. Jego powtórne odkrycie, przypomnienie wygnania — „ziarna choroby”, powoduje „,chaos”, który ,jak przypływ się wdziera” w spokojne już życie. Stanowi ono zagrożenie całej „harmonii świata”, stworzonego przez kobietę. Jest to sygnał ciągle powracającej Polski, wydarzeń minionych. Przeszłość i teraźniejszość stanowią w emigrantce jedność: „bo było tylko to co było / i jest co jest” Nad oceanem (WSL, s. 70). Wypędzona nie może wyzbyć się tej części tożsamości, mimo że powoduje ona zamieszanie, tęsknotę za dawną ojczyzną. Pokazuje to użyta po raz kolejny metafora pękniętego drzewa: „ta sama jabłoń / stoi tam a pień / na dwa istnienia / bólem rozczepiony” Pień (ZSMW, s. 5). Ból rozdarcia między Polską a Ameryką naznacza ją na wieczność oraz doprowadza do wniosku, że wygnanie nie kończy się tam, gdzie aktualnie przebywa: przez „Kanion dolnego Broadwayu” Przejdziemy tędy (ŁJIJP, s. 13) tylko się przechodzi, ,tak jak się przechodzi / przez życie / że minęło / tylko się zdziwimy”. Ten problem otwarcie pokazuje bardzo krótki, lecz wymowny wiersz Nowy Jork (ŁJIJP, s. 15):

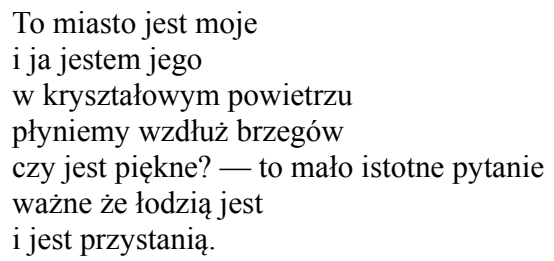

[29 lipca 2001]

Mówi w nim bardzo dojrzały podmiot liryczny. Zauważalna jest przemiana w obrębie myślenia o mieście. Wcześniej tym, co zachwycało wygnaną, był krajobraz. Teraz ważniejszy jest nie wygląd miasta, lecz to, czym się dla niej stało. Jest ono bowiem „łodzią”, na której może płynąć przez życie, i ,przystanią”, miejscem, które ją przygarnęło na emigracji, daje wytchnienie, można $\mathrm{w}$ nim metaforycznie przystanąc przed dalszą wędrówką do wiecznej Ziemi Obiecanej, kresu wygnania, bo tylko: „,- Jeruza- 
lem niebieskie — / w przepastnych fałdach dogmatu. / Ono nie jest historią" Historia (WSL, s. 61).

Wiersze Anny Frajlich pokazują, że akceptacja stanu wygnania nie prowadzi do jego zakończenia. Polska tożsamość emigrantki powoduje jej ciągły powrót — we wspomnieniach oraz podróżach — do kraju lat dziecinnych. Pomimo że tęsknota wzmaga chęć osiedlenia się tam, porzucenia Ameryki, poetka widzi, że po tylu latach i doświadczeniach nie jest to już możliwe. Mimo upływającego czasu Polska nadal funkcjonuje w jej świadomości jako Pardes Poloniae. Żydowska część osobowości natomiast tęskni za Edenem, rzeczywistością przedwygnaniową, błogą i bez cierpienia, którą można osiągnąć dopiero po śmierci, w Jerozolimie Niebieskiej.

\section{LITERATURA:}

K. Adamczyk, Antynostalgia i nostalgia. Rzecz o wygnaniu, [w:] tegoż, Doświadczenia polsko-żydowskie w literaturze emigracyjnej (1939-1980), Kraków 2008, s. 166;

Biblia Jerozolimska, thum. zespół biblistów, wstępy, przypisy, komentarze i marginalia thum. zespół pod kier. ks. A. Cholewińskiego i bp. Z. Kiernikowskiego, Poznań 2006;

Z. Borzymińska, Niewola babilońska, [w:] Polski słownik judaistyczny Dzieje - kultura religia - ludzie, oprac. Z. Borzymińska, R. Żebrowski, Warszawa 2003, t. 2, s. 229-230;

M. E. Cybulska, Uwikłana wśród żywiołów (O liryce Anny Frajlich), Przegląd Polski 1981, 0410.11., s. 5A-7A;

A. Frajlich, Aby wiatr namalować, Londyn 1976;

-, Between Dawn and the Wind, Austin, Texas 2006;

—, Drzewo za oknem (arkusz poetycki z grafikami Bartka Małysy), Nowy Jork 1991;

-, Indian Summer, Nowy Jork, 1982;

—, Jeszcze w drodze. Wybór wierszy, Warszawa 1994;

-, Który las, Londyn 1986;

-, Lodzia jest i jest przystania, Szczecin 2013;

-, Marzec zacząt się w czerwcu, Midrasz 1998, nr 3, s. 6-8;

—, Ogrodem i ogrodzeniem, Warszawa 1993,;

-, Tylko ziemia, Londyn 1979;

—, W stońcu listopada, Kraków 2000;

—, Znów szuka mnie wiatr, Warszawa 2001;

A. Frajlich, N. Gross, Anna Frajlich: o sobie i o swoich wierszach, Nowiny Kurier 17.08. 2001, s. $17-18,22$;

W. Gniatczyński, „Audycja o nowym tomiku wierszy Anny Frajlich” (maszynopis), Radio „Wolna Europa”, [brak daty emisji], s. 1-9;

R. Grol, Erotyka $i$ wygnanie. Poezja Anny Frajlich, thum. Tomasz Kunz, [w:] Życie w przektadzie, red. H. Stephan, Kraków 2001, s. 99-112;

N. Gross, Miejsce na ziemi, Nowiny Kurier 7.09.2001;

H. Grynberg Henryk, Tylko ziemia, poezja i miłość, Wiadomości 1979 nr 44 (1753);

M. Karpińska Marta, Poety emigracyjnego zmagania z biografia (na przykładzie twórczości Anny Frajlich), Akcent 2005 nr 3, s. 76-84;

J. Kubitsky, Psychologia migracji, Warszawa 2012;

W. Ligęza, Jerozolima i Babilon. Miasta poetów emigracyjnych, Kraków 1998;

—, Lampa w oknie, Rzeczpospolita 2000 nr 179, s. E5;

-, Poeta emigracyjny. Role i wyobrażenia, [w:] Literatura a wyobcowanie, red. J. Święch, Lublin 1990, s. 79-91;

W. Micha, Etyczny wymiar tożsamości etnicznej w sytuacji zmiany identyfikacji narodowej, [w:] Etyczny wymiar tożsamości kulturowej. Studia z antropologii spotecznej, red. M. Flis, Kraków 2004, s. 25-45;

Obserwator, Anna Frajlich w POSK-u, Dziennik Polski i Dziennik Żołnierza 16.12.1978, s. 12; 
M. Peretz, Indian Summer Anny Frajlich, Przegląd Polski, 28.10-03.11.1982, s. 7;

G. Scholem, O głównych pojęciach judaizmu, tłum. J. Zychowicz, Warszawa 1989;

F. Śmieja, Do trzech razy sztuka, Związkowiec 1983 nr 6;

-, Malarka wiatru, Związkowiec 1977 nr 8, s. 4;

Ch. Taylor, Etyka autentyczności, tłum. A. Pawelec, Kraków-Warszawa 1996;

—, Źródła podmiotowości: narodziny tożsamości nowoczesnej, tłum. M. Gruszczyński, Warszawa 2001;

A. Węgrzyniakowa, Po Marcu, [w:] Literatura emigracyjna 1939-1989, red. J. Garliński, Z. Jagodziński, J. Olejniczak, I. Opacki, t. 1, Katowice 1994, s. 147-161;

—, Życie w podróży. O liryce Anny Frajlich, [w:] „Ktokolwiek jesteś bez ojczyzny...”, red. W. Ligęza, W. Wyskiel, Łódź 1995, s. 299-312;

S. Wygodzki Stanisław, Zwierzenia spisane wierszem, Nowiny Kurier 21.10.1977, s. 8;

J. Żmidziński Jakub, Drzewo i dom. O wierszach Anny Frajlich-Zajac, Polonistyka $1998 \mathrm{nr} 6$, s. 371-373;

S. J. Żurek, Sam na sam z poezja, Akcent 2003 nr 4, s. 164-166.

\section{AMERICA IN ANNA FRAJLICH'S POETRY}

This article focuses on the representations of the United States in Anna Frajlich's autobiographical work. Selected poems explore the transformations in her perception of their country of immigration. At first, the poet introduces America as a place of banishment after the events in Poland in March 1968, as a country where it is possible to live but difficult to feel at home. Later, she emphasises the beauty and delight over the American landscape and culture, and of New York in particular. Finally, she presents America as her new home and the place where she has put down new roots. However, this is not the end of the pilgrimage for the poet because for the Jewish nation that she is part of, this end never comes. Therefore, in the last volume of poetry, New York is referred to as "a boat and a haven" rather than a port. A change in thinking about herself and her life is the result of the transformation of the subject's perception of America. The banished woman gradually accepts her fate, gets used to it and decides to live in the present. However, she does not reject the past which has largely determined her identity. If it had not been for her Jewish origin she would not have been banished from Poland. It leads the poet to a better self-understanding, to a new definition of herself as a human being, a woman, a Jew, a Pole and an American.

KEYWORDS: Anna Frajlich; United States in poetry; banishment in poetry; America and exile. 